\title{
Evaluasi Kecernaan In Vitro Complete Feed Fermentasi Berbahan Dasar Ampas Sagu dengan Teknik Fermentasi Berbeda
}

\author{
(Digestibility Evaluation In Vitro Complete Feed Fermentation Sago Residues Based with \\ Different Fermentation Techniques)
}

\author{
Sugrahadi Ahmad Aprianto ${ }^{1}$,Asrii ${ }^{1}$, Yunasri Usman ${ }^{1}$ \\ ${ }^{1}$ Program Studi Peternakan, Fakultas Pertanian, Universitas Syiah Kuala
}

\begin{abstract}
Abstrak. Penelitian ini telah dilaksanakan di Laboratorium Ilmu Nutrisi dan Makanan Ternak Program Studi Peternakan Fakultas Pertanian Universitas Syiah Kuala dan dilanjutkan dengan pengiriman sampel penelitian ke Laboratorium Ternak Perah Institut Pertanian Bogor (IPB) untuk pengujian kecernaan secara in vitro. Tujuan dari penelitian ini adalah menguji kecernaan secara in vitro complete feed berbahan dasar ampas sagu dengan teknik fermentasi yang berbeda.Pembuatan complete feed disusun sesuai dengan kebutuhan ternak domba. Penelitian ini menggunakan Rancangan Acak lengkap (RAL) dengan 3 perlakuan dan masing-masing perlakuan terdiri atas 5 ulangan. Perlakuan 1 (kontrol) adalah complete feed tanpa penambahan Saus Burger Pakan (SBP) dan tanpa fermentasi, perlakuan 2 adalah ampas sagu difermentasi dengan SBP selama 14 hari kemudian dicampur menjadi complete feed dan difermentasi hingga 21 hari, sedangkan perlakuan 3 adalah ampas sagu + complete feed kemudian difermentasi dengan SBP selama 21 hari. Parameter yang diamati dalam penelitian ini adalah pH, Bahan Kering (BK), Bahan Organik (BO), Koefisien Cerna Bahan Kering (KCBK), dan Koefisien Cerna Bahan Organik (KCBO). Hasil pengamatan menyimpulkan bahwa, teknik fermentasi yang berbeda berpengaruh sangat nyata $(\mathrm{P}<0,01)$ terhadap semua parameter yang diamati, yaitu $\mathrm{pH}, \mathrm{BK}, \mathrm{BO}, \mathrm{KCBK}$ dan KCBO. Dari hasil penelitian dapat disimpulkan bahwa nilai kecernaan complete feed berbahan dasar ampas sagu dipengaruhi oleh perbedaan teknik fermentasi.
\end{abstract}

Kata kunci : ampas sagu, teknik fermentasi, In Vitro, $\mathrm{pH}$ dan kecernaan

Abstract. This research was conducted at the Laboratory of Nutrition and Feed Studies, Program study Animal Husbandry, Faculty of Agriculture, University of Syiah Kuala and continued with the delivery of sample to the Laboratory of Dairy Cattle Institute Pertanian Bogor (IPB) for testing of in vitro digestibility. The purpose of this study was to test in vitro digestibility of complete feed made from the residues of sago with different fermentation techniques. Complete feed was arranged based on the needs of sheep. This study used a complete randomized design (CRD) with 3 treatments and each treatment consisted of 5 replicates. Treatment 1 (control) was a complete feed without the addition of Saus Burger Pakan (SBP) and without fermentation, treatment 2 was sago residu fermented with SBP for 14 days and then mixed into a complete feed and fermented up to 21 days, whereas treatment 3 was the sago residue + complete feed then fermented with SBP for 21 days. The parameters observed in this study were $\mathrm{pH}$, Dry Matter (BK), Organic Matter (BO), Dry Matter digestibility coefficients (KCBK), and Organic Matter Digestibility Coefficient (KCBO). The result influence showed that, different fermentation technique was significantly $(\mathrm{P}<0.01)$ all parameters, namely $\mathrm{pH}, \mathrm{BK}, \mathrm{BO}, \mathrm{KCBK}$ and $\mathrm{KCBO}$. It can be concluded that the digestibility of complete feed made from sago residue influenced by differences in fermentation techniques.

Keywords: sago residues, fermentation techniques, in vitro, $\mathrm{pH}$ and digestibility

\section{PENDAHULUAN}

Penyediaan pakan hijauan untuk ternak ruminansia sampai saat ini masih mengalami beberapa masalah, antara lain jumlah produksi yang berfluktuasi sepanjang tahun. Ketersediaan hijauan pada musim kemarau lebih sedikit dibandingkan dengan musim hujan mengakibatkan pada musim kemarau ternak akan kekurangan pakan. Kendala diatas dapat diatasi dengan pemanfaatan pakan hijauan yang berasal dari limbah pertanian dan perkebunan, salah satu limbah industri pertanian yang juga dapat dimanfaatkan sebagai bahan pakan ternak adalah limbah dari industri pengolahan sagu berupa ampas sagu. Ampas sagu seperti juga dengan industri pertanian lainnya memiliki kandungan nutrisi yang rendah. 
Menurut Tampoebolon (2009) dari keseluruhan sagu hanya 18,5\% merupakan pati sementara sisanya $(81,5 \%)$ adalah ampas sagu. Selanjutnya diinformasikan bahwa kandungan serat kasar ampas sagu adalah 28,30\% dengan kandungan protein sekitar 1,36\%. Rendahnya kandungan protein ampas disertai tingginya kandungan serat kasar ampas sagu akan menyebabkan kondisi dan fungsi rumen kurang baik, sehingga diperlukan penambahan bahan pakan lain penyusun complete feed untuk memperbaikinya. Fermentasi juga merupakan salah satu teknologi untuk meningkatkan kualitas pakan asal limbah, karena adanya keterlibatan mikroorganisme yang mendegradasi serat kasar, mengurangi kadar lignin dan senyawa anti nutrisi, sehingga dapat meningkatkan nilai kecernaan pakan asal limbah (Wina, 2005).

Kecernaan pakan sangat penting untuk diketahui sebelum pakan diaplikasikan ke ternak. Harfiah (2007) menyatakan, proses penentuan kecernaan pakan pada ternak ruminansia dapat dilakukan dengan 3 metode yaitu in vivo, in sacco maupun in vitro. Metode kecernaan in vivo adalah metode kecernaan yang dapat ditentukan dengan menggunakan ternak secara langsung. Kecernaan in vivo dilakukan dengan mencatat pakan yang dikonsumsi dan dikurangi dengan jumlah feses yang dikeluarkan dalam waktu 24 jam. Kecernaan in sacco merupakan salah satu metode pengukuran degradasi pakan didalam rumen dengan menggunakan hewan yang berfistula rumen (Kurniawan, 2007; Askari 2012; Ristianto, 2012).

Mulyawati (2009) dan Sudirman (2013) menyatakan, metode kecernaan in vitro merupakan metode pengukuran kecernaan suatu bahan pakan yang dilakukan di laboratorium dengan meniru proses terjadinya kecernaan pakan didalam saluran pencernaan ternak ruminansia. Secara tidak langsung kita dapat mengamati kegiatan yang terjadi didalam rumen dengan cara in vitro. Faktor yang mempengaruhi kecernaan in vitro antara lain pencampuran pakan, cairan rumen, pengontrolan temperatur, larutan penyangga (saliva buatan), variasi waktu dan metode analisis.

Complete feed adalah campuran pakan antara hijauan dan konsentrat yang diberikan kepada ternak sesuai dengan kebutuhan nutrisi ternak. Bahan yang digunakan sebagai Complete feed dapat berasal dari limbah pertanian dan industri pertanian, sehingga perlu ditingkatkan kualitasnya. Salah satu metode yang digunakan adalah dengan cara fermentasi. Data tentang kecernaan in vitro yang berkaitan dengan teknik fermentasi seperti memfermentasi bahan limbah dilanjutkan dengan fermentasi dengan Complete feed atau fermentasi Complete feed sekaligus masih terbatas. Oleh karena itu perlu dilakukan penelitian tentang pengaruh teknik fermentasi yang berbeda terhadap kecernaan in vitro Complete feed.

\section{MATERI DAN METODE PENELITIAN}

\section{Tempat dan Waktu Penelitian}

Penelitian ini dilaksanakan di Laboratorium Ilmu Nutrisi dan Makanan Ternak Program Studi Peternakan Fakultas Pertanian Universitas Syiah Kuala dan dilanjutkan dengan pengiriman sampel penelitian ke Laboratorium Ternak Perah Institut Pertanian Bogor (IPB) untuk pengujian kecernaan secara in vitro. Penelitian ini berlangsung selama 40 hari mulai 23 Januari sampai dengan 02 Maret 2016.

\section{Materi Penelitian}

Materi yang digunakan dalam penelitian ini adalah cairan rumen, complete feed yang berbahan dasar ampas sagu. Saus burger pakan (SBP) digunakan untuk proses fermentasi. 


\section{Metode Penelitian}

Metode yang dipakai dalam penelitian ini adalah metode eksperimen, dengan menggunakan Rancangan Acak Lengkap (RAL) yang terdiri atas 3 perlakuan dengan masing-masing 5 ulangan, sehingga didapat 15 unit perlakuan.

Variabel yang diamati dalam penelitian ini adalah $\mathrm{pH}$ cairan rumen, koefisien cerna bahan kering (KCBK) dan koefisien cerna bahan organik (KCBO) secara in vitro. Data penelitian yang diperoleh dianalisis dengan analisis sidik ragam (Analisis of Variance/ANOVA), dan apabila terdapat perbedaan antar perlakuan dilanjutkan dengan uji Duncan (Stell dan Torrie, 1989).

Tabel 1. Formulasi bahan pakan penelitian yang disusun berdasarkan kebutuhan ternak domba

\begin{tabular}{lcccc}
\hline Bahan Pakan & $\%$ & P1 & P2 & P3 \\
\cline { 3 - 5 } & & & $(\mathrm{Kg})$ & \\
\hline Ampas Sagu & 40.0 & 2.4 & 2.4 & 2.4 \\
Dedak Kasar & 9.0 & 0.54 & 0.54 & 0.54 \\
Bungkil Kelapa & 15.2 & 0.912 & 0.912 & 0.912 \\
Bungkil Kedelai & 15.0 & 0.9 & 0.9 & 0.9 \\
Kulit Ari Kedelai (KAK) & 4.0 & 0.24 & 0.24 & 0.24 \\
Rumput Gajah (Hay) & 7.5 & 0.45 & 0.45 & 0.45 \\
Lamtoro (Hay) & 5.0 & 0.3 & 0.3 & 0.3 \\
Urea & 0.8 & 0.048 & 0.048 & 0.048 \\
Molases & 2.0 & 0.12 & 0.12 & 0.12 \\
NaCl & 0.5 & 0.03 & 0.03 & 0.03 \\
Mineral & 1.0 & 0.06 & 0.06 & 0.06 \\
SBP & 0.3 & - & 0.018 & 0.018 \\
\hline Total & 100 & 6 & 6 & 6 \\
\hline Ketrangan & & &
\end{tabular}

Keterangan :

$\mathrm{P} 1=$ ampas sagu + complete feed (kontrol) tanpa fermentasi

$\mathrm{P} 2=$ ampas sagu fermentasi SBP $(0,3 \%) 14$ hari + complete feed di fermentasi 21 hari

P3 = ampas sagu + complete feed (di fermentasi SBP 0,3\%) fermentasi 21 hari

\section{Tahap fermentasi}

Untuk tahap pertama aktifkan mikroba terlebih dahulu dengan menimbang molasses sebanyak 2,0\% dari total keseluruhan bahan pakan, timbang SBP sebanyak 0,3\% dari seluruh bahan pakan. Sediakan air sebanyak 1,5 liter untuk pembuatan $6 \mathrm{~kg}$ pakan, kemudian campurkan antara molasses dan SBP tersebut kedalam 1,5 liter air lalu aduk sampai homogen dan diamkan selama 1 jam agar mikroba pada SBP aktif.

Pada tahap selanjutnya timbang bahan pakan masing-masing berdasarkan persentase yang sudah ditentukan (ampas sagu 40\%, dedak kasar 9,0\%, bungkil kelapa 15,2\%, bungkil kedelai15,0\%, kulit ari kacang kedelai 4,0\%, rumput gajah (hay) 7,5\%, lamtoro (hay) 5,0\%, urea $0,8 \%, \mathrm{NaCl} 0,5 \%$, mineral $1 \%$ ). Campurkan bahan pakan tersebut didalam wadah secara berlapis dengan bahan pakan yang persentasenya lebih besar diletakkan pada lapisan paling bawah lalu diikuti oleh bahan-bahan dengan persentase yang lebih kecil. Aduk sampai semua bahan pakan benar-benar homogen. Lakukan penyiraman larutan mikroba yang telah diaktivasi dalam campuran air dan molasses pada bahan Complete feed yang telah tercampur, kemudian tahapan selanjutnya aduk kembali bahan pakan yang telah disiram larutan hingga 
merata dimana hal ini bertujuan agar larutan mikroba terserap dan merata keseluruhannya pada bahan pakan konsentrat.

Pada tahap terakhir complete feed yang telah disiram larutan mikroba dan telah di aduk sampai homogen disimpan (peram) dalam wadah yang kedap udara. Pemeraman untuk perlakuan ampas sagu fermentasi, difermentasi selama 14 hari terlebih dahulu lalu setelah itu campur dengan bahan Complete feed lainnya dan difermentasi kembali selama 21 hari, setelah 21 hari bahan pakan siap untuk dianalisis. Perlakuan Complete feed fermentasi diperam selama 21 kemudian bahan pakan siap dianalisis. Fermentasi yang baik ditandai dengan warna pakan yang kecoklat-coklatan dan berbau harum seperti caramel.

Pakan fermentasi (substrat) dikeringkan di oven pengering selama 3-4 hari dengan temperatur $55^{\circ} \mathrm{C}-60^{\circ} \mathrm{C}$ kemudian analisis bahan kering dilakukan dengan menggunakan metode analisis proksimat sesuai petunjuk (AOAC, 1990). Untulk analisis Koefisien Cerna Bahan Kering dan Koefisien Cerna Bahan Organik secara In Vitro dilakukan metode analisis menutut Tilley dan Terry (1963).

\section{HASIL DAN PEMBAHASAN}

\section{Nilai pH Cairan Rumen}

Nilai $\mathrm{pH}$ sangat menmpengaruhi aktivitas mikroba di dalam rumen. Nilai $\mathrm{pH}$ yang rendah akan menyebabkan suasana rumen menjadi asam dan menurunkan aktivitas dan populasi mikroba rumen terutama bakteri selulolitik yang peka terhadap suasana asam sehingga akan menghambat proses degradasi pakan. Menurut Wibawati (2013) pH adalah derajat keasaman yang digunakan untuk menyatakan tingkat keasaman atau kebasaan suatu larutan. Nilai $\mathrm{pH}$ suatu larutan dinyatakan netral jika berada pada angka 7, bersifat asam jika nilai $\mathrm{pH}$ kurang dari 7 dan bersifat basa atau alkali bila nilai $\mathrm{pH}$ lebih dari 7 . Nilai $\mathrm{pH}$ sangat mempengaruhi aktivitas mikroba dalam rumen. Rataan nilai $\mathrm{pH}$ in vitro fermentasi completed feed berbahan dasar ampas sagu dengan teknik fermentasi berbeda tersaji pada Gambar 1 .

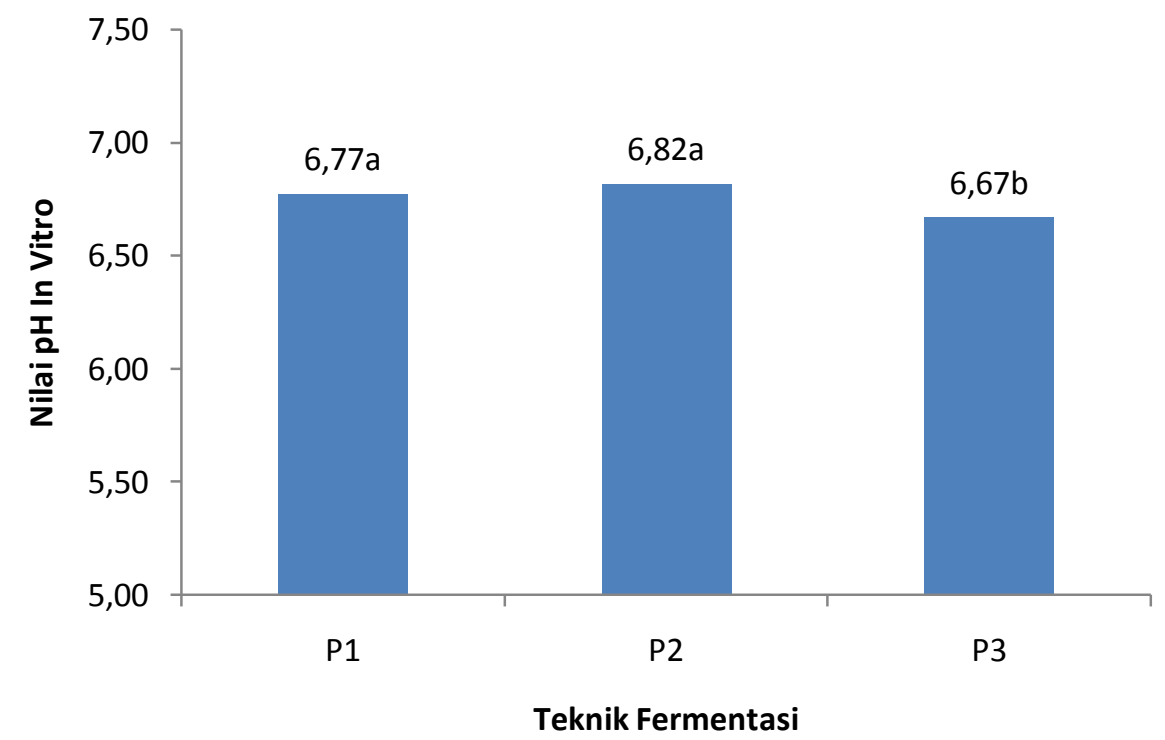

Gambar 1. Rataan nilai $\mathrm{pH}$ In Vitro complete feed fermentasi $(\mathrm{P} 1=$ Ampas sagu + complete feed (kontrol), P2= Ampas sagu fermentasi SBP $(0,3 \%)+$ complete feed, $\mathrm{P} 3=$ Ampas sagu + complete feed (di fermentasi SBP $0,3 \%$ ) 
Dari hasil analisis sidik ragam terlihat bahwa rataan nilai $\mathrm{pH}$ cairan rumen in vitro fermentasi completed feed berbahan dasar ampas sagu tidak menunjukkan adanya perbedaan antara $\mathrm{P} 1$ dan $\mathrm{P} 2$ tetapi menunjukkan perbedaan sangat nyata $(\mathrm{P}<0.01)$ terhadap $\mathrm{P} 3$ dan masih dalam kisaran yang memenuhi syarat untuk berlangsungnya fermentasi pakan baik didalam rumen maupun secara in vitro. Usman (2013) berpendapat bahwa mikroba rumen secara efektif akan mendegradasi pakan serat apabila nilai $\mathrm{pH}$ berada pada kisaran 6,5-7 dan aktivitas pencerna serat akan melambat jika $\mathrm{pH}$ berada pada nilai 6,2. Semakin rendah nilai $\mathrm{pH}$ menunjukkan semakin tinggi tingkat fermentasi oleh mikrobia rumen. Hal ini menunjukkan bahwa lingkungan rumen berada dalam keadaan seimbang, sehingga proses fermentasi berjalan seimbang. Selama pemeraman terjadi penurunan $\mathrm{pH}$ yang dipengaruhi oleh jumlah asam laktat yang dihasilkan oleh bakteri asam laktat (BAL) yang terdapat dalam $\mathrm{SBP}$, semakin tinggi asam laktat yang dihasilkan maka $\mathrm{pH}$-nya semakin rendah (Soeza et al., 2003).

\section{Koefisien Cerna Bahan Kering (KCBK)}

Kecernaan bahan kering merupakan bagian dari bahan kering dalam pakan yang dicerna oleh hewan pada tingkat konsumsi pakan tertentu. Kecernaan pakan pada ternak ruminansia sangat erat hubungannya dengan jumlah dan aktivitas mikroba dalam rumen dan daya tampung rumen. Menurut Orskov (2002) suhu, pH, kapasitas buffer, tekanan osmotik, kandungan bahan kering dan potensial reduksi-oksidasi adalah faktor utama yang mempengaruhi pertumbuhan, aktivitas dan populasi mikroba rumen.

Hasil penelitian menunjukkan, koefisien cerna bahan kering (KCBK) complete feed fermentasi berbahan dasar ampas sagu dengan teknik fermentasi yang berbeda berkisar antara 61,77\% sampai 70,58\%. Rataan nilai KCBK dapat dilihat pada Gambar 2 di bawah ini.

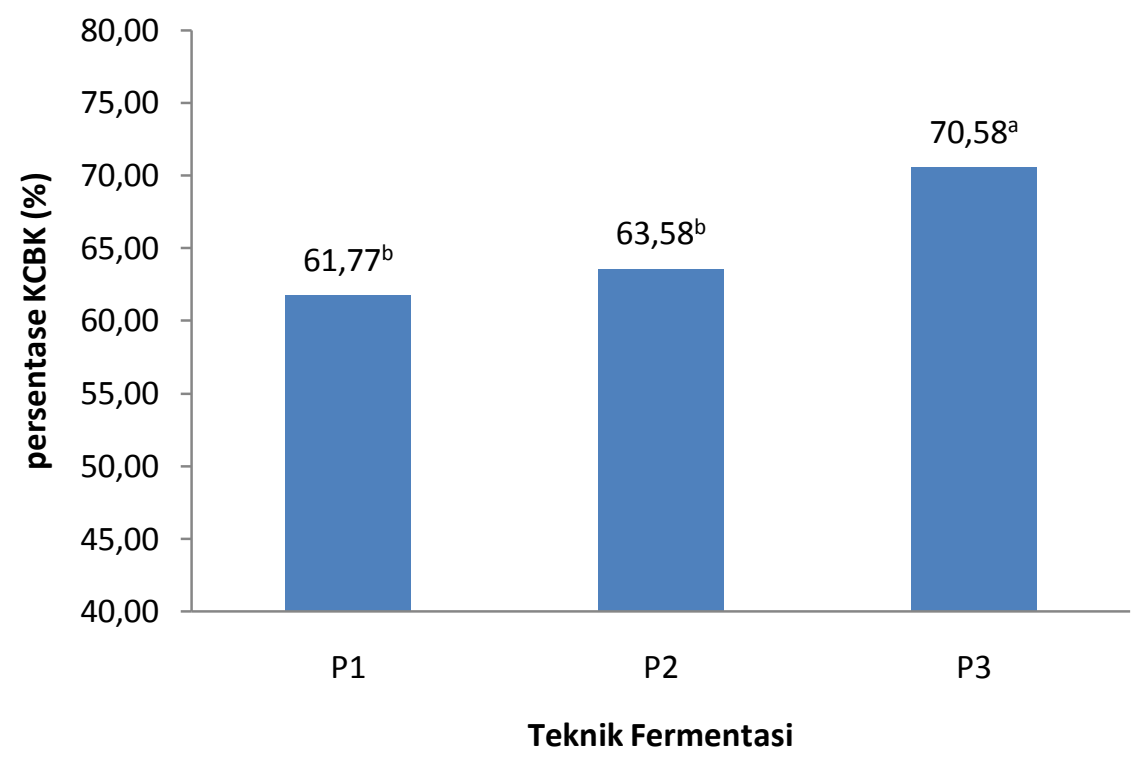

Gambar 2. Rataan Persentase KCBK Complete feed fermentasi $(\mathrm{P} 1=$ Ampas sagu + complete feed (kontrol), P2 = Ampas sagu fermentasi SBP $(0,3 \%)+$ complete feed, $\mathrm{P} 3=$ Ampas sagu + complete feed $(\mathrm{di}$ fermentasi SBP $0,3 \%$ )

Hasil analisis sidik ragam menunjukkan, teknik fermentasi complete feed berbahan dasar ampas sagu berpengaruh sangat nyata $(\mathrm{P}<0,01)$ terhadap nilai KCBK. Pada Gambar 7 
terlihat, nilai KCBK terendah terjadi pada perlakuan P1 (kontrol) yaitu 61,77\% dan nilai KCBK tertinggi terjadi pada perlakuan P3 yaitu 70,58\%. Meningkatnya nilai KCBK pada P3 disebabkan oleh tercukupinya sumber energi yang dibutuhkan mikroba untuk berkembang dan mendegradasi serat kasar. Sesuai pendapat Harry (2007), tercukupinya sumber energi selama proses fermentasi berlangsung, digunakan mikroba untuk kebutuhan hidupnya sehingga meningkatkan kinerjanya dalam mendegradasi serat kasar substrat.

Peningkatan populasi bakteri rumen berkaitan erat dengan jalannya proses fermentasi berbagai nutrien pakan baik selulosa, hemiselulosa maupun bahan-bahan terlarut lainnya (Bata, 2008). Menurut Anitasari (2010), kecernaan bahan kering yang tinggi pada ternak ruminansia menunjukkan tingginya zat nutrisi yang dicerna oleh mikroba rumen. Rendahnya kecernaan bahan kering yang diperoleh diduga disebabkan oleh beberapa faktor antara lain jenis pakan, komposisi ransum, jumlah mikroba maupun umur sapi (Tilman et al., 1991).

\section{Koefisien Cerna Bahan Organik}

Kecernaan bahan organik didalam saluran pencernaan ternak meliputi kecernaan zatzat makanan yang berupa komponen bahan organik seperti karbohidrat, protein, lemak dan vitamin. Faktor yang mempengaruhi kecernaan bahan organik adalah kandungan serat kasar dan mineral dari bahan pakan.Kecernaan bahan organik sangat erat kaitannya dengan kecernaan bahan kering, karena sebagian dari bahan kering terdiri atas bahan organik dan anorganik. Prawirokusumo (1994) berpendapat bahwa menurunnya kecernaan bahan kering akan mengakibatkan penurunan kecernaan bahan organik, demikian juga sebaliknya.

Hasil penelitian menunjukkan, koefisien cerna bahan organik (KCBO) completed feed fermentasi berbahan dasar ampas sagu dengan teknik fermentasi yang berbeda berkisar antara 63,13\% sampai 71,39\%. Rataan nilai KCBO dapat dilihat pada Gambar 3 di bawah ini.

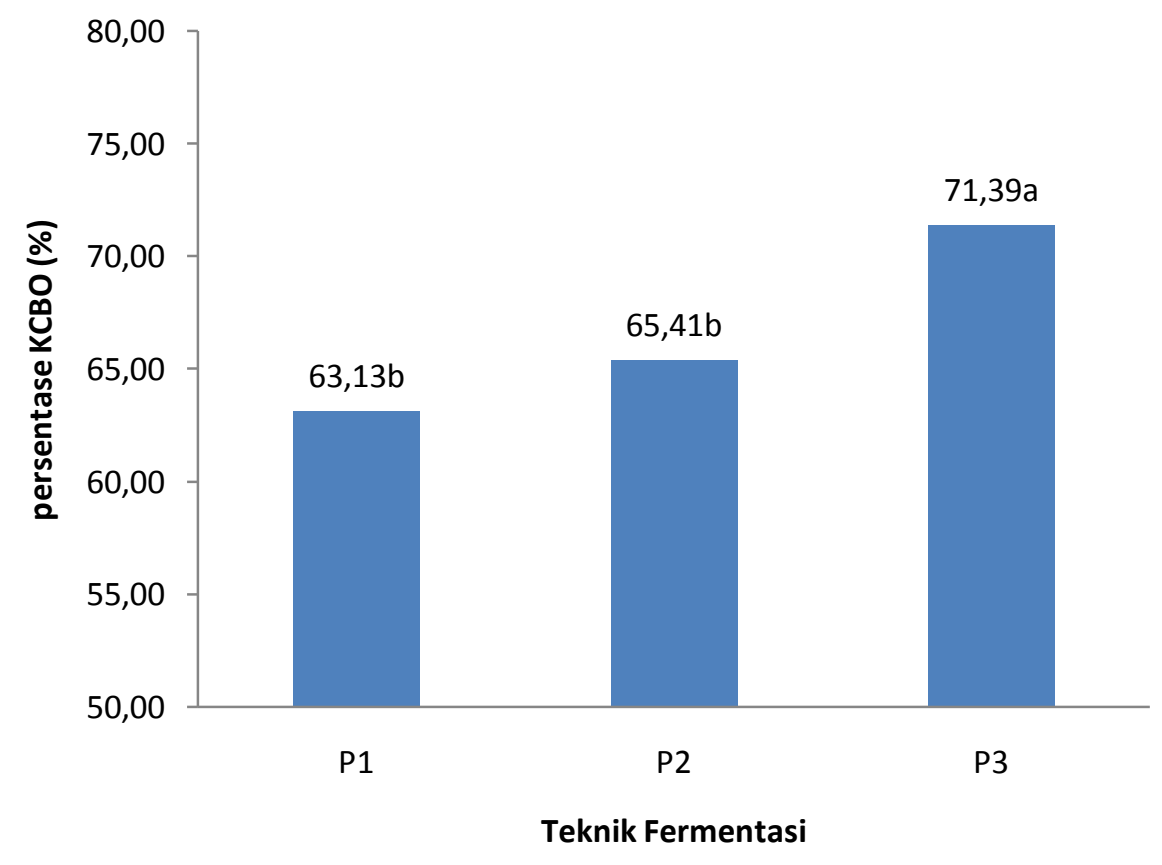

Gambar 3. Rataan Persentase KCBO complete feed fermentasi $(\mathrm{P} 1=$ Ampas sagu + complete feed (kontrol), $\mathrm{P} 2=$ Ampas sagu fermentasi SBP $(0,3 \%)+$ complete feed, $\mathrm{P} 3=$ Ampas sagu + complete feed (di fermentasi SBP 0,3\%) 
Hasil analisis sidik ragam menunjukkan, teknik fermentasi completed feed berbahan dasar ampas sagu berpengaruh sangat nyata $(\mathrm{P}<0,01)$ terhadap nilai $\mathrm{KCBO}$. Rataan nilai KCBO P3 sangat nyata $(\mathrm{P}<0,01)$ lebih tinggi dari perlakuan lainnya. Tingginya nilai $\mathrm{KCBO}$ pada perlakuan P3 diduga karena pada saat fermentasi bakteri memperoleh sumber energi yang cukup, sehingga bekerja optimal dalam mendegradasi serat dan mikroba rumen mudah mendegradasinya dalam saluran pencernaan. Selulosa adalah salah satu bahan organik yang terdapat dalam jumlah banyak dan merupakan energi yang sangat potensial bagi ruminansia, apabila selulosa telah di degradasi sempurna dan cepat maka dapat diharapkan mampu meningkatkan kecernaan bahan organik (Munasik 2007). Bahan pakan yang memiliki kandungan nutrien yang sama memungkinkan nilai $\mathrm{KCBO}$ mengikuti KCBK, namun juga dapat terjadi perbedaan karena dipengaruhi oleh bentuk dan ukuran fisik pakan, jumlah dan jenis mikroba pakan yang terdapat di dalam rumen (Munasik 2007).

\section{KESIMPULAN DAN SARAN}

Teknik fermentasi berbeda pada complete feed berbahan dasar ampas sagu berpengaruh sangat nyata terhadap nilai $\mathrm{pH}$, persentase kandungan Bahan Kering (BK), dan Bahan Organik (BO) in vitro, koefisien cerna bahan kering (KCBK) dan koefisien cerna bahan organik $(\mathrm{KCBO})$ secara in vitro. Teknik fermentasi pada perlakuan ampas sagu + complete feed yang difermentasi 21 hari memberikan hasil yang terbaik ditandai dengan tingginya nilai $\mathrm{KCBK}$ dan KCBO.

Untuk memperoleh informasi yang lebih menyeluruh mengenai peningkatan nilai kecernaan complete feed fermentasi berbahaan dasar ampas sagu dengan teknik fermentasi yang berbeda, penelitian ini dapat dilanjutkan secara in sacco maupun secara in vivo pada ternak.

\section{DAFTAR PUSTAKA}

Anitasari, A.2010. Pemamfaatan Senyawa Bioaktif Kembang Sepatu (Hibiscus rosa-sinensis) untuk menekan Produksi Gas Metan pada Ternak Ruminansia. IPB. Bogor.

AOAC. 1990. Official Methods of Analisis. Association of Official Analitycal Chemist. AOAC. Washington DC. USA.

Askari.M .Z., 2012. Evaluasi Kecernaan Beberapa Bahan pada Ternak Peranakan Ongole (PO) dan Peranakan Frisian Holstein (PFH).[skripsi]. Universitas Gadjah Mada, Yogyakarta.

Bata, M., dan B. Rustomo. 2008. Peningkatan Kinerja Sapi Potong Lokal Melalui Rekayasa Amoniasi Jerami Padi Menggunakan Molases dan Limbah Cair Tapioka. Laporan Hasil Penelitian Fakultas Peternakan Unsoed, Purwokerto.- 2123.

Harfiah, 2007. Nilai Indeks Beberapa Pakan Hijauan Potensial Untuk Ternak Domba. Prosidding. Seminar Nasional Teknologi Peternakan dan veteriner 2007. Universitas Hasanuddin. Makassar.

Harry, T.U., 2007. Peningkatan Nilai Nutrisi Ampas Sagu (Metroxilon Sp.) Melalui Bio Fermentasi. Balai Pengkajian Teknologi Pertanian Papua Barat, Manokwari.

Kurniawan, M. R. 2007. Kecernaan In vivo Jerami Kacang Tanah (Arachis hypogaea) Pada Kerbau. Skripsi. Fakultas Peternakan Universitas Gadjah Mada. Yogyakarta. 
Mulyawati, Y. 2009. Fermentabilitas dan kecernaan in vitro biomineral dienkapsulasi. Fakultas Peternakan, Institut Pertanian Bogor.

Munasik. 2007. Pengaruh Umur Pemotongan Terhadap Kualitas Hijauan Sorgum Manis (Shorgum biocolor L. Moench) Varietas. RGU. Prosiding seminar Nasional: 248-253.

Orskov, E. R. 2002. Trials and Trials In Livestock Research. Andi Offest. Yogyakarta.

Prawirokusumo,S., 1994. Ilmu Gizi Komparatif. BPFE, Jogjakarta

Ristianto, U. 2012. Evaluasi Pakan dengan Metode Noninvasif. PT. Citra Aji Parama. Yogyakarta.

Souza, C. G. ; Ferreira, dos, Santos, M. V. ; Silva, M. C. ; Cunha, M. V. ; Lira, M. A., 2003. Qualitative measures of Panicum maximum Jacq.cultivar under nitrogen fertilisation. Revista Caatinga

Sudirman. 2013. Evaluasi Pakan Tropis, dari Konsep ke Aplikasi ( Metode In Vitro Feses). Pustaka Reka Cipta, Bandung.

Tampuebolon, B. I.M. 2009. Kajian perbedaan aras dan lamaa pemeraman fermentasi ampas sagu dengan aspergillus niger erhadap kandungan protein kasar dan serat kasar. Seminar nasional kebangkitan peternakan. Semarang.

Tilley, J.M. A. dan R.A. Terry, 1963. The relationship between the soluble constitutent herbage and their dry matter digestibility. J. British Feed Sci. 18: 104-111

Tillman, A.D., H. Hartadi., S. Reksohadiprodjo., S. Prawirokusumo., S. Lebdosoekojo. 1991. Ilmu Makanan Ternak Dasar. Yogyakarta: Gajah Mada Univresity Press.

Usman. Y. 2013. Pemberian pakan serat sisatanaman pertanian (Jerami Kacang Tanah, Jerami Jagung, Pucuk Tebu) Terhadap Evolusi pH, N-NH dan VFA didalam Rumen Sapi. Jurnal Agripet vol 13 nomor 2 oktober 2013. Universitas Syiah Kuala. Banda Aceh.

Wibawati, P.A. 2013. Pengaruh Ekstrak Daun Sirih Terhadap Kecernaan Pakan Ruminansia. [Skripsi]. Fakultas Kedokteran Hewan. Universitas Airlangga.

Wina, Elizabeth. 2005. Teknologi Pemanfaatan Mikroorganisme dalam Pakan Untuk Meningkatkan Produktivitas Ternak Ruminasia di Indonesia : sebuah review. Wartazoa Vol 15.No 4 Tahun 2005,. Bogor. 173-186. 